\title{
The Application of The Quantum Teaching Model with Multimedia to Improve The Students' Learning Outcomes of Social Science about Types of Jobs on Grade III Students of SDN Jatimulyo in Academic Year 2018/2019
}

\author{
Wahyu Khasanah ${ }^{1}$, Muh. Chamdani ${ }^{2}$, Ratna Hidayah ${ }^{3}$ \\ 1,2,3 Universitas Sebelas Maret \\ wahyukhasanah09@gmail.com
}

\section{Article History}

accepted 01/06/2019

\begin{abstract}
This study aimed to improve social science learning outcomes about the types of jobs on third grade students of SDN Jatimulyo in Academic Year 2018/2019 through the application of quantum teaching and multimedia models. This research is a collaborative classroom action research (CAR) carried out in three cycles. The subjects of this study were teachers and third grade students of SDN Jatimulyo. Data collection techniques used test techniques, observation, and interviews. Data validity test used technical triangulation and source triangulation. Data analysis included data reduction, data presentation, and conclusion. The conclusion of this study is the application of the quantum teaching model with multimedia that is implemented according to the scenario could improve social science learning outcomes about the types of jobs on third grade students of SDN Jatimulyo in Academic Year 2018/2019.
\end{abstract}

Keywords: quantum teaching, multimedia, social science learning outcomes

\begin{abstract}
Abstrak
Penelitian ini bertujuan untuk meningkatkan hasil belajar ilmu sosial tentang jenis pekerjaan pada siswa kelas tiga SDN Jatimulyo pada Tahun Ajaran 2018/2019 melalui penerapan pengajaran kuantum dan model multimedia. Penelitian ini adalah penelitian tindakan kelas kolaboratif (PTK) yang dilaksanakan dalam tiga siklus. Subjek penelitian ini adalah guru dan siswa kelas tiga SDN Jatimulyo. Teknik pengumpulan data menggunakan teknik tes, observasi, dan wawancara. Uji validitas data menggunakan triangulasi teknis dan triangulasi sumber. Analisis data meliputi reduksi data, penyajian data, dan penarikan kesimpulan. Kesimpulan dari penelitian ini adalah penerapan model pengajaran kuantum dengan multimedia yang diterapkan sesuai dengan skenario dapat meningkatkan hasil belajar ilmu sosial tentang jenis pekerjaan pada siswa kelas tiga SDN Jatimulyo pada Tahun Ajaran 2018/2019.
\end{abstract}

Kata kunci: quantum teaching, multimedia, hasil belajar ilmu sosial 


\section{PENDAHULUAN}

Seiring perkembangan zaman, tuntutan terhadap pendidikan kian meningkat. Mulai dari tuntutan perbaikan kurikulum, tenaga pendidik, sampai fasilitas sarana prasarana sebagai upaya meningkatkan mutu kualitas pendidikan di Indonesia. Salah satu dari pelajaran yang ada di sekolah yaitu Ilmu Pengetahuan Sosial. Pada Permendiknas Nomor 22 Tahun 2006 tentang standar isi dinyatakan bahwa:

Di waktu yang akan datang siswa akan menghadapi tantangan berat karena kehidupan masyarakat global selalu mengalami perubahan setiap saat. Oleh karena itu mata pelajaran IPS dibuat untuk mengembangkan pengetahuan, pemahaman dan kemampuan analisis terhadap keadaan sosial masyarakat dalam memasuki kehidupan bermasyarakat yang dinamis.

Dari uraian tersebut, dapat diketahui bahwa IPS ialah pelajaran yang penting bagi siswa sebagai bekal kehidupan bermasyarakat kelak, sesuai dengan pendapat Susanto (2016: 144), pendidikan IPS adalah suatu kajian terpadu dari ilmu sosial dan kemanusiaan yang bertujuan untuk meningkatkan kemampuan kewarganegaraan. Namun, seringkali kita mendengar bahwa mata pelajaran IPS cenderung membosankan bagi siswa.

Berdasarkan observasi dan wawancara peneliti di SDN Jatimulyo pada hari Kamis, 6 September 2018, didapatkan bahwa guru merasa kesulitan untuk menciptakan suasana pembelajaran yang tidak membosankan bagi siswa, terkhusus pada pembelajaran IPS. Tuntutan banyaknya materi yang harus disampaikan membuat guru memilih untuk mengajarkan dengan ceramah. Selain itu, berdasarkan observasi dan wawancara yang dilakukan, didapatkan data bahwa hasil belajar IPS siswa kelas III tergolong rendah. Dari siswa yang mengikuti ulangan harian pertama pelajaran IPS, terdapat sekitar $1 / 2$ dari jumlah siswa yang hasilnya mencapai KKM yaitu 70. Untuk lebih rincinya $57 \%$ siswa kelas III mencapai $\mathrm{KKM}$, sisanya $43 \%$ belum mencapai KKM.

Rendahnya persentase siswa yang mencapai KKM tersebut dikarenakan beberapa hal seperti cara guru dalam menyampaikan materi pembelajaran IPS yang masih didominasi dengan kegiatan ceramah, jarang menerapkan model dan media, kemudian siswa hanya menjadi objek pembelajaran. Selain itu, materi yang luas menjadikan guru menggunakan sistem hafalan bagi siswa, padahal kemampuan menghafal siswa berbeda dan biasanya sistem hafalan tidak akan membekas lama dibenak siswa. Hal tersebut membuat siswa mudah merasa bosan, cenderung pasif, kurang termotivasi, dan pada akhirnya kurang memperhatikan materi yang disampaikan dalam pembelajaran.

Berdasarkan kondisi tersebut, peneliti merasa perlu adanya variasi kegiatan dalam pembelajaran IPS. Variasi yang dapat dilakukan salah satunya yaitu penerapan model dan media. Model yang diterapkan ialah model yang mampu menciptakan suasana pembelajaran yang menyenangkan, memudahkan dalam memahami materi, dan mempertajam memori ingatan siswa. Selain itu, media yang diterapkan ialah media yang mampu menarik perhatian dan minat siswa, serta membuat pembelajaran lebih interaktif. Salah satu model dan media yang cocok diterapkan ialah model quantum teaching dengan multimedia.

Model quantum teaching yang seringkali dikenal dengan TANDUR merupakan model yang menyenangkan, hal tersebut sesuai dengan pendapat DePorter, Readon, dan Singer-Nourie (2011: 32) yang menyatakan bahwa quantum teaching ialah model yang menggubah suasana belajar menjadi meriah dengan semua nuansanya, menyertakan segala kaitan, interaksi, dan perbedaan yang memaksimalkan momen belajar.

Di sisi lain, multimedia seringkali dikenal sebagai media yang berkaitan dengan teknologi. Selain itu, penerapan multimedia akan melibatkan berbagai jenis media untuk merangsang semua indera dalam satu kegiatan pembelajaran yang lebih 
menekankan pada media berbasis TIK (Asyhar, 2012: 77). Pada penerapan multimedia biasanya merangsang indera pendengaran melalui audio dan indera penglihatan melalui visual. Hal tersebut sesuai dengan pendapat Alkhasawneh (2016: 96) yang mengemukakan bahwa multimedia mencakup lebih dari satu bentuk media seperti konferensi teks, grafik, animasi, audio, video animasi, dan video yang mampu memberikan berbagai rangsangan.

Pembelajaran melalui penerapan model quantum teaching dengan multimedia pada materi IPS tentang jenis pekerjaan tentunya akan lebih bermakna. Guru nantinya mampu menciptakan suasana pembelajaran yang menyenangkan serta mampu memberikan pengetahuan yang lebih tentang beragam jenis pekerjaan yang jarang ditemukan di lingkungan siswa, sehingga siswa diharapkan mudah memahami materi yang disampaikan guru serta memiliki wawasan luas yang nantinya bisa dijadikan bekal kaitannya dengan pekerjaan yang siswa cita-citakan.

Berdasarkan pemaparan di atas, peneliti melaksanakan penerapan model quantum teaching dengan multimedia untuk meningkatkan hasil belajar IPS tentang jenis pekerjaan pada siswa kelas III SDN Jatimulyo tahun ajaran 2018/2019.

\section{METODE}

Penelitian ini merupakan penelitian tindakan kelas yang dilaksanakan di kelas III SDN Jatimulyo, Kecamatan Alian, Kabupaten Kebumen. Subjek penelitian ini adalah guru dan siswa kelas III yang berjumlah 23 siswa. Pada penelitian ini terdapat dua jenis data yaitu data kuantitatif berupa hasil belajar IPS tentang jenis pekerjaan dan data kualitatif berupa informasi tentang pelaksanaan pembelajaran model quantum teaching dengan multimedia terhadap peningkatan hasil belajar dalam bentuk deskriptif teks.

Teknik pengumpulan data menggunakan teknik tes dan teknik non tes (observasi dan wawancara). Uji validitas data menggunakan triangulasi teknik dan triangulasi sumber. Menurut Miles dan Huberman (Sugiyono, 2015: 337-345), alur menganalisis data terbagi tiga, yaitu: reduksi data, penyajian data, dan penarikan kesimpulan.

Indikator kinerja penelitian ini adalah peningkatan hasil belajar IPS siswa dengan ketercapaian target $85 \%$, dengan KKM hasil belajar yaitu 70 . Penelitian ini menggunakan prosedur penelitian Kemmis dan Taggart (Arikunto, 2013: 137), prosedur pelaksanaan penelitian tindakan kelas meliputi tahap perencanaan, pelaksanaan, observasi, dan refleksi.

HASIL DAN PEMBAHASAN

Data hasil observasi dari 3 observer terkait penerapan model quantum teaching dengan multimedia sebagai berikut.

Tabel 1. Hasil Observasi terhadap Guru dan Siswa

\begin{tabular}{|c|c|c|c|c|}
\hline & \multicolumn{3}{|l|}{ Siklus } \\
\hline & & $\mathrm{I}$ & II & III \\
\hline Guru & Persen & 74,31 & 83,68 & 92,01 \\
\hline Siswa & Persen & 72,22 & 80,90 & 90,28 \\
\hline
\end{tabular}

Berdasarkan tabel 1, dapat disimpulkan bahwa pada setiap siklus mengalami peningkatan, sehingga dapat diartikan bahwa penerapan dari langkah-langkah model quantum teaching dengan multimedia setiap siklusnya juga semakin meningkat. Persentase guru dan siswa pada siklus III telah menunjukkan bahwa indikator kinerja yang ditargetkan telah tercapai. 
Berdasarkan penelitian, dari keenam langkah penerapan model quantum teaching dengan multimedia, siswa paling antusias pada saat pelaksanaan langkah keenam, yaitu rayakan. Mereka merasa sangat senang mendapatkan hadiah, kemudian suasana pembelajaran yang seru karena menonton video sebagai relaksasi otak mereka. Hal tersebut sesuai dengan pendapat Kosasih dan Sumarna (Supramono, 2016: 84) yang menyatakan bahwa aspek rayakan dalam kerangka pembelajaran TANDUR merupakan pengakuan terhadap pencapaian siswa, penyelesaian aktivitas dalam proses pembelajaran, partisipasi dalam proses pembelajaran serta pemerolehan keterampilan dan pengetahuan yang patut dihargai.

Selain hasil observasi, berikut peningkatan hasil tes evaluasi siswa pada pembelajaran melalui penerapan model quantum teaching dengan multimedia pada siklus I, II, dan III.

Tabel 2. Peningkatan Hasil Belajar

\begin{tabular}{llll}
\hline & $\begin{array}{l}\text { Siklus } \\
\text { I }\end{array}$ & $\begin{array}{l}\text { Siklus } \\
\text { II }\end{array}$ & $\begin{array}{l}\text { Siklus } \\
\text { III }\end{array}$ \\
\hline Tuntas & 73,91 & 84,78 & 93,48 \\
\hline $\begin{array}{l}\text { Belum } \\
\text { Tuntas }\end{array}$ & 26,08 & 15,22 & 6,52 \\
\hline
\end{tabular}

Berdasarkan tabel 2, dapat disimpulkan bahwa pada setiap siklus mengalami peningkatan hasil belajar IPS siswa. Persentase hasil belajar IPS siswa pada siklus III telah menunjukkan bahwa indikator kinerja yang ditargetkan telah tercapai. Lebih lanjut lagi, dapat diketahui bahwa langkah-langkah dalam penerapan model quantum teaching dengan multimedia pada pembelajaran IPS tentang jenis pekerjaan dapat meningkatkan hasil belajar IPS. Hal ini didukung karena model pembelajaran quantum teaching a) mampu meningkatkan minat siswa, b) materi akan mudah dicerna, c) merangsang kreativitas siswa, pengetahuan siswa akan lebih besar, d) guru mudah mengontrol pencapaian hasil belajar siswa, e) memori siswa akan lebih tajam, f) siswa lebih percaya diri dan antusias, dan g) merupakan model yang mampu membuat suasana pembelajaran segar dan mengalir (Rumapea, Syahputra, dan Surya, 2017: 122).

\section{SIMPULAN}

Berdasarkan analisis pelaksanaan penelitian, hasil penelitian dan pembahasan maka dapat disimpulkan bahwa penerapan model quantum teaching dengan multimedia dapat meningkatkan hasil belajar IPS tentang jenis pekerjaan.

\section{DAFTAR PUSTAKA}

Alkhasawneh, S. (2016) The Effect of Multimedia-Aided Teaching on Kindergarten Children Mathematical Achievement and Attitude. Paripex Indian Journal of Reasearch, 5(4). 96.

Arikunto, S. (2013). Prosedur Penelitian Suatu Pendekatan Praktik. Jakarta: Rineka Cipta.

Asyhar, R. (2012). Kreatif Mengembangkan Media Pembelajaran. Jakarta: Gaung Persada Press Jakarta.

Depdiknas. (2006). Permendiknas RI Nomor 22 Tahun 2006 tentang Standar Isi Untuk Satuan Pendidikan Dasar dan Menengah. Jakarta: BSNP.

DePorter, B., Readon, M., dan Singer-Nourie, S. (2011). Quantum Teaching. Bandung: Kaifa. 
Volume 7 Nomor 2 Tahun 2019

Rumapea, G., Syahputra, E., dan Surya, E. (2017). Application of Quantum Teaching Learning Model to Improve Student Learning Outcomes. International Journal of Novel Research in Education and Learning. Vol. 4, Issue 2, pp: (118-130).

Sugiyono. (2015). Metode Penelitian Pendidikan. Bandung: Alfabeta.

Susanto, A. (2016). Teori Belajar dan Pembelajaran di Sekolah Dasar. Jakarta: Prenada Media Grup.

Yahya, H. (2016). Pengaruh Penerapan Model Pembelajaran Quantum Teaching Terhadap Hasil Belajar Biologi Siswa SMS Islam Terpadu Al-Fityan Gowa. Jurnal Biotek. Volume 5, No 1. 